\title{
Understanding the Nexus of R\&D Expenditures and Intangible Assets in Different Asset Types: A Quantile Regression Approach
}

\author{
Geoffrey VanderPal \\ Purdue University Global
}

The financial outcomes of research and development $(R \& D)$ expenditures and intangible assets are not instantaneous and straightforward. To explore the varied perspectives of these relationships, quantile regression technique is used to understand whether and how such relationships vary for the firms with different financial strength. The findings provide insights in risk-return paradigm of $R \& D$ investment and the successive return, besides helping the policy makers to settle the priority sector, to get the expected result in line with country's investment policy.

\section{INTRODUCTION}

Research and Development (R\&D) is indispensable for the survival in this progressively competitive business environment. To thrive in this competitive environment, there is a bigger demand for R\&D. The firms which allocate higher R\&D expenditure are expected to earn more than those that do not (ChaoHung Wang, 2011). Corporate R\&D expenditures are largely focused on creating knowledge assets, intangible in nature and partly implanted in human capital, and customarily very specialized to the particular industry in which it exist in (Hall \& Lerner, 2010). Within an industry, intangible asset(s) is the main factor of differentiation and competitiveness of enterprises (Penman, 2009). Hence, in order to gain competitive advantage, firms undertake costly R\&D activities to innovate. (Thatcher \& Pingry, 2009). Successful R\&D activities aid in increasing firm's value and bear significance for corporate managers. So, the relationship between R\&D expenses and financial performance is vital for firm's managers whose aim is to maximize the present values of stocks (Tubbs, 2007).

Recognizing the significance in recent years, there has been an increasing interest among academics from different field of studies to understand the relationship dynamics between R\&D expenditures and financial performance. Investment in $\mathrm{R} \& \mathrm{D}$ are considered in relation to other intangible investments, as an important form of investment (Leitner, 2005). At large, R\&D expense and intangibles have positive effects on firm value and profitability and an indicator for future financial performance (Chen, Cheng, \& Hwang, 2005). However, previously published studies on the effect of R\&D expenses and intangible assets are not consistent.

This study aims to contribute to this growing area of research by exploring the relationship from diverse viewpoints. The study aims to examine the role of \&D expense and intangible assets on firms' financial performance. Besides looking into the R\&D expense and intangible assets, it also considers the ratio of such $\mathrm{R} \& \mathrm{D}$ expense to operating income (post operating income expense), to have an understanding in a relative manner. Also, it considers the ratio of intangible assets to firm's total assets to recognize how the possession of intangibles are beneficial, from the perspective of firm's asset holding. 
Considering the financial strength endogeneity, analyzing the impact of R\&D expenses and intangible assets on performance for the firms in different asset types gives the study a novel profoundness.

Firms' expenditures are, however, often not a straightforward, but rather a contingent decision. Firms are less willing to reduce their R\&D levels following a negative growth shock than they are willing to increase R\&D after a positive shock (Coad and Rao, 2009). They provide a comprehensive analysis by considering US manufacturing firms from 1973 - 2004 with focus on the co-evolution of sales growth, employment growth, profits growth and the growth of R\&D expenditure. They also confirm that sales growth has a more persistent influence on the R\&D growth. However, firms are not very keen to reduce their R\&D expenditure levels following a negative growth shock as much as they are willing to increase R\&D after a positive shock, based on the performance feedback of firms that adjust their level of investment in R\&D continuously (Jirásek, 2017). In addition, the level of R\&D expenditure and financial performance relationship varies according to the nature of business, with the link being more powerful for more productive and innovative organisations (Pandit, Wasley, \& Zach, 2009).

Relatively, firms which invest in R\&D are found to have formed a positive correlation between R\&D intensity and the company's performance; and, the impact of R\&D investments is two times higher on market capitalisation as compared with investments in tangible assets (Hsieh et al., 2003). On average, a firm that engages in R\&D activities earns $4 \%$ to $11 \%$ higher sales and generates $4 \%$ to $13 \%$ more profits than firms that do not engage in R\&D activities (Rafiq, Salim, \&Smyth, 2016). Yet, the consequences are not instantaneous and mostly dependent on the time lag between the moment the R\&D spending was incurred and the point at which it improved financial sustainability, which varies from business to business (Dave, Wadhwa, Aggarwal, \& Seetharman, 2013). Martin (2015) established a strong variant in terms of the efficiency of various categories of inventive expenditure, by evaluating the effectiveness of various types of business innovation expenditures of manufacturing enterprises. He found relatively strong and consistently positive lagged random effects (RE) of both internal and external R\&D expenditure.

Bearing this in mind, firms employ a large portion of their R\&D investments in strengthening their intangible asset types. Innovation is usually positively correlated with return on assets (Sher and Yang, 2005; Gamayuni, 2015). Yet, the propensity to invest in intangible assets are not homogeneous and surges according to the firm's size, human capital, and historical intangible asset base (Arrighetti, Landini, \& Lasagni, 2014). Moreover, the value of intangible assets is more volatile than the value of tangible assets, and any change increases the difference between the book value and market value (Garger, 2010).

Firms used to spend on R\&D as innovation is perceived as a valuable source of a firm's performance and competitive advantage. In relation to the idea that $R \& D$ initiatives can be a highly uncertain undertaking, Kothari, Laguerre, and Leone (2002) compared the unpredictability of future benefits driven by $R \& D$, which in theory create intangible assets, with the potential performance of capital expenditure (CAPEX) that is likely to lead to tangible assets. The authors documented a positive correlation between $R \& D$ and the variation in future earnings of the firms; and designated that the advantages driven by $R \& D$ are relatively more uncertain.

Past studies have discussed the impacts of possessing intangible assets and the key issue investigated was on the interconnection between R\&D expenditure and consequential performance of firms, particularly their financial performance. The effect of such expenditure was found to be heterogeneous for growing or shrinking firms (Coad \& Rao, 2009). Such mix outcomes may occur due to the variations among R\&D related dependent measures (Jirásek, 2018). Nonetheless, most researchers conclude that investment in R\&D has positive impact on profitability (Lin, Yang \& Liou, 2008; Martin, 2015; Jirásek, 2017). In certain cases however, some authors have failed to find a significant relationship between firms' R\&D spending and performance (Shin, Kraemer \& Dedrick, 2008). There are also research findings that the decision to capitalise R\&D is often associated with a negative or neutral impact on future performance (Cazavan-Jeny, Jeanjean and Joos, 2011). The inconclusiveness in the current literature points to the need for further investigation to ascertain the relationship between R\&D investments made by firms along with the impact of intangible assets. 
Quantile regression, developed by Koenker and Bassett (1978), is an extension of the classical least squares estimation of the conditional mean to a collection of models for different conditional quantile functions. As the median (quantile) regression estimator minimizes the symmetrically weighted sum of absolute errors (where the weight is equal to 0.5) to estimate the conditional median (quantile) function, other conditional quantile functions are estimated by minimizing an asymmetrically weighted sum of absolute errors, where the weights are functions of the quantile of interest in behavior between underperforming and over-performing stocks, or firms that may be receiving negative or positive idiosyncratic shocks, and that such behavior differs for large as opposed to small firms. The quantile regression technique therefore provides considerable insight that cannot be obtained by using standard regression techniques. We analyze the time series of returns using quantile regression methods. Long data set eliminate time period bias that is attributed to period by period shocks in data adjustement process. In this adjustment process time series bias are being estimated and then removed through a systematic process

Quantile regression technique is used to understand whether and how such relationships vary for the firms with different financial strength.

\begin{tabular}{|c|l|l|l|}
\hline 1. & $\begin{array}{l}\text { To find out how the } \\
\text { relationship varies is } \\
\text { in different asset } \\
\text { types. }\end{array}$ & $\begin{array}{l}\text { Different quantiles of } \\
\text { corporate asset (AST) }\end{array}$ & $\begin{array}{l}\text { Simulative Quantile Regression analysis to } \\
\text { understand the R\&D expenditure- } \\
\text { performance or intangibles-performance } \\
\text { nexus for different sized companies } \\
\text { (assets); i.e. comparative analysis of } \\
\text { companies in } 25 \% \text { and } 75 \% \text { quantiles. }\end{array}$ \\
\hline
\end{tabular}

TABLE 1

\section{LIST OF VARIABLES}

\begin{tabular}{lc}
\hline Variable Name & Symbol \\
\hline Assets-Total & AST \\
EBIT & EBI \\
Net Income (Loss) & NEI \\
Op Income Bef Depreciation & OPI \\
Price-Close Calendar Year & PRI \\
R\&D Expense & RDE \\
ROA & ROA \\
ROE & ROE \\
Sales-Net & SAL \\
R\&D Expense ratio & RDE/OPI \\
\hline
\end{tabular}


FIGURE 1 VARIABLES IN DIFFERENT QUANTILES
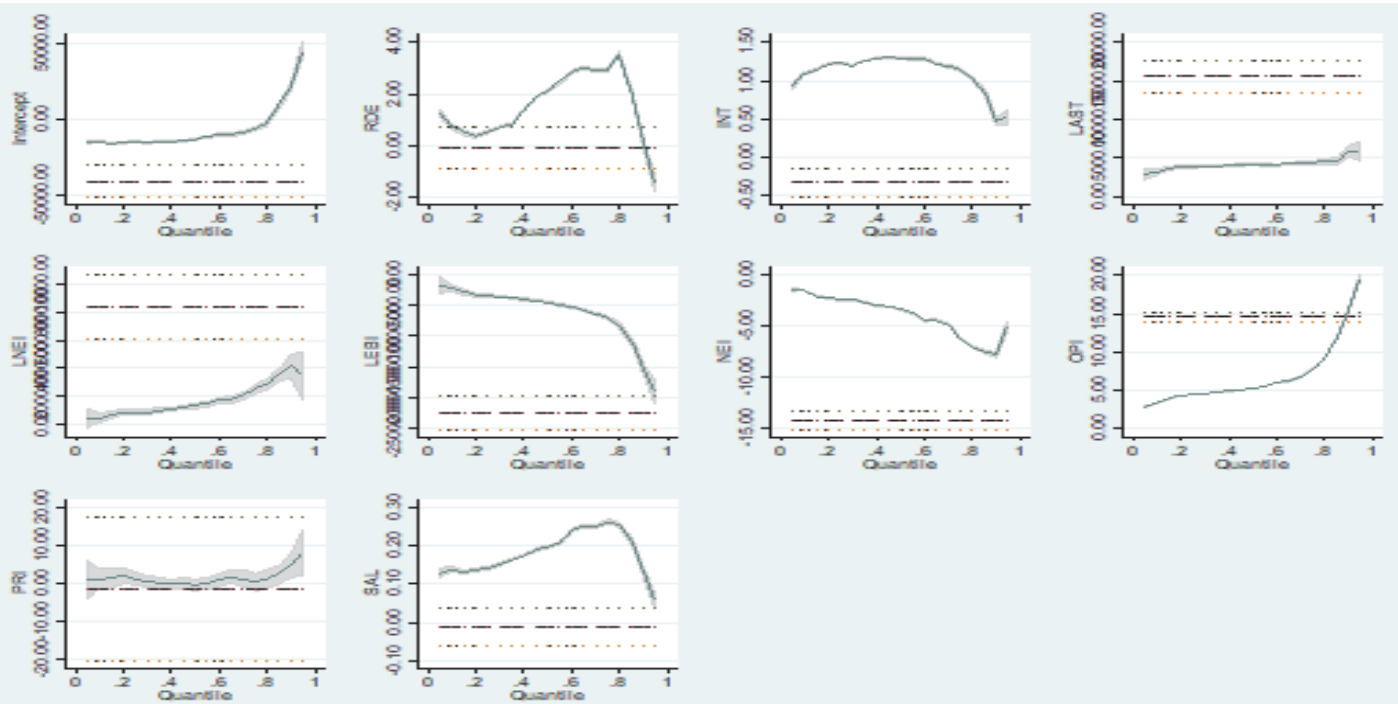

Graph Matrix Reported p-values are constructed using the design matrix bootstrap approach and hence are robust to serial correlation, heteroskedasticity and any general dependence between the regressors and the regression errors. From the graph we can also see that the variables are non-linear in nature and show the evidence of differences in different quantiles.

TABLE 2

\section{QUANTILE REGRESSION}

\begin{tabular}{lllll}
\hline & ROA 0.25 & ROA 0.75 & ROE 0.25 & ROE 0.75 \\
\hline RDE & $0.0000515^{* * *}$ & $0.000300^{* * *}$ & $-0.000301 * * *$ & -0.000438 \\
& $(4.57)$ & $(5.53)$ & $(-3.46)$ & $(-1.66)$ \\
INT & $-0.0000208^{* * *}$ & -0.0000102 & $-0.0000681 * * *$ & $-0.000165^{* *}$ \\
& $(-8.25)$ & $(-0.84)$ & $(-3.52)$ & $(-2.82)$ \\
LAST & $-6.960^{* * *}$ & $-7.168^{* * *}$ & $-9.377 * * *$ & $-11.33^{* * *}$ \\
& $(-255.07)$ & $(-54.65)$ & $(-44.14)$ & $(-17.61)$ \\
LNEI & $5.705^{* * *}$ & $3.758^{* * *}$ & $3.802 * * *$ & $3.898^{* * *}$ \\
& $(181.82)$ & $(24.92)$ & $(15.66)$ & $(5.30)$ \\
LEBI & $1.121 * * *$ & $2.789 * * *$ & $6.748 * * *$ & $9.435^{* * *}$ \\
& $(29.48)$ & $(15.26)$ & $(22.89)$ & $(10.56)$ \\
NEI & $0.0000715^{* * *}$ & $0.000256^{* * *}$ & $0.000225^{*}$ & 0.000363 \\
& $(5.94)$ & $(4.43)$ & $(2.43)$ & $(1.29)$ \\
OPI & 0.0000107 & -0.0000111 & -0.0000897 & -0.000166 \\
& $(1.46)$ & $(-0.31)$ & $(-1.59)$ & $(-0.97)$
\end{tabular}




\begin{tabular}{|c|c|c|c|c|}
\hline PRI & $\begin{array}{l}0.00121 * * * \\
(4.64)\end{array}$ & $\begin{array}{l}0.00240 \\
(1.91)\end{array}$ & $\begin{array}{l}-0.00444^{*} \\
(-2.04)\end{array}$ & $\begin{array}{l}0.0107 \\
(1.62)\end{array}$ \\
\hline SAL & $\begin{array}{l}-0.00000144 * \\
(-2.11)\end{array}$ & $\begin{array}{l}-0.00000594 \\
(-1.81)\end{array}$ & $\begin{array}{l}0.00000450 \\
(0.86)\end{array}$ & $\begin{array}{l}0.0000227 \\
(1.43)\end{array}$ \\
\hline Constant & $\begin{array}{l}25.81 * * * \\
(184.31)\end{array}$ & $\begin{array}{l}30.14 * * * \\
(44.77)\end{array}$ & $\begin{array}{l}28.29 * * * \\
(26.04)\end{array}$ & $\begin{array}{l}35.23 * * * \\
(10.70)\end{array}$ \\
\hline Observations & 2959 & 2959 & 2891 & 2891 \\
\hline
\end{tabular}

All of the individual firm-specific tests resoundingly reject the null hypothesis that the coefficients are the same across the quantiles. This result may in part be due to the data containing fewer large firms than small firms. The market-wide factors generally do not significantly differ across the quantiles when considered individually, but conjointly, the coefficients on these factors are very significant. Also, joint tests of the null that the coefficients on all firm-specific and market-wide factors are equal to zero are also strongly rejected across all quantiles and firm sizes. For ROE, RDE has significant effect in $25 \%$ quantile, but no significant in $75 \%$ quantile. Also for intangible assets it has significant effect in $25 \%$ quantile but insignificant in $75 \%$ quantile.

\begin{tabular}{|l|l|l|l|l|l|}
\hline $\begin{array}{l}\text { To find out how } \\
\text { the relationship } \\
\text { varies is in } \\
\text { different asset } \\
\text { types. }\end{array}$ & $\begin{array}{l}\text { Different } \\
\text { quantiles of } \\
\text { corporate } \\
\text { asset (AST) }\end{array}$ & ROA & $25 \%$ & $\begin{array}{l}\text { Both R\&D and } \\
\text { Intangible assets } \\
\text { significant }\end{array}$ & $\begin{array}{l}\text { Significant Difference is } \\
\text { found in different } \\
\text { quantiles of asset size. }\end{array}$ \\
\cline { 3 - 5 } & ROE & $25 \%$ & $\begin{array}{l}\text { Intangible assets } \\
\text { not significant }\end{array}$ & $\begin{array}{l}\text { Both R\&D and } \\
\text { Intangible assets } \\
\text { significant }\end{array}$ \\
\cline { 3 - 4 } & & $75 \%$ & $\begin{array}{l}\text { R\&D not } \\
\text { significant }\end{array}$ & \\
\cline { 3 - 5 } & & $75 \%$ & & \\
\hline
\end{tabular}

The current study intended to examine the relationship between R\&D expense and corporate financial performance as well such how such financial performance is influenced by firms' intangible assets. To do so, the study considers the ratio of R\&D expense and operating income and the ratio of intangible assets to firm's total assets besides considering R\&D expenses and intangibles assets to measure the relationship. By employing the data from S\&P 500 companies over the period of 1979 to 2015, the study finds diverse outcomes concerning the relationship. Mostly, the R\&D expenses affect financial performance negatively, whereas intangible assets was not found significant to influence the corporate financial performance. Moreover, the current study considers the financial strength endogeneity by investigating the influence of $R \& D$ expenses on performance for the firms in dissimilar asset types. Through quantile regression analysis, significant difference is found in different quantiles of asset size.

The research findings possess significant policy implications for different types of stakeholders, as R\&D expenditures and intangible assets are intense concerns for various parties. For the investors, the findings provide insights in risk-return paradigms in the framework of investment risk in R\&D activities and intangible asset holdings by the firms and their subsequent return.

In addition, this study contains noteworthy insights for the policy makers, government agencies and regulatory bodies; returns generated through $\mathrm{R} \& \mathrm{D}$ expenditures and intangible assets are vital to decide on the benefits, subsidization, taxation policy and such. Further, it is expected to aid the policy makers to settle on which sectors are worth prioritizing and how much support to get the expected result in line with the country's investment policy. Also, notably the study adds value to academia by considering R\&D 
expenses and intangibles' influence on corporate performance which is not clear in the existing literature. Besides answering some unsettled research problems and adding knowledge to the growing body of literature in this filed, the study unveils further avenue of research for academics.

The study endeavoured comprehensive analyses and fairly novel attempt to understand the nexus; nevertheless, it is not devoid of some limitations mostly owing to unavailability of adequate data. The dataset comprises only S\&P 500 companies which are predominantly large companies based on developed economy (i.e. the USA), thus leads to lack of generalizability of the findings for the companies around the globe. Also, in some cases sufficient sectoral data were not available and levied restrictions on analyses. Likewise, the study did not take into consideration the institutional and governance variables. Since significant difference is found in the asset-equity structure of the companies, further analyses with such variables could have been more insightful. Correspondingly, the analyses do not expands to consider regional variations of the firms' spending in R\&D activities, thus the study does not provide how the relationship varies region-wise, i.e. how the developed country firms get benefits from R\&D expenses and intangibles assets compared to developing ones. Hence, future research may consider new dataset and incorporate regional analyses by giving consideration for institutional and political variables which will stretch better generalizability of the research. Furthermore, study can be further extended by considering threshold and asset size effect for different sectors as the current finding is somewhat heterogeneous.

\section{REFERENCES}

Arrighetti, A., Landini, F., \& Lasagni, A. (2014). Intangible assets and firm heterogeneity: Evidence from Italy. Research Policy, 43(1), 202-213.

Bottazzi, G., \& Secchi, A. (2003). Common properties and sectoral specificities in the dynamics of US manufacturing companies. Review of Industrial Organization, 23(3-4), 217-232.

Bottazzi, G., Secchi, A., \& Tamagni, F. (2007). Productivity, profitability and financial fragility: empirical evidence from Italian business firms.

Cainelli, G., Evangelista, R., \& Savona, M. (2005). Innovation and economic performance in services: a firm-level analysis. Cambridge Journal of Economics, 30(3), 435-458.

Cazavan-Jeny, A., Jeanjean, T., \& Joos, P. (2011). Accounting choice and future performance: The case of R\&D accounting in France. Journal of Accounting and Public Policy, 30(2), 145-165.

Cecchetti, S., \& Kharroubi, E. (2012). Reassessing the impact of finance on growth (No. 381). Bank for International Settlements.

Cha, H. S., Pingry, D. E., \& Thatcher, M. E. (2009). What determines IT spending priorities? Communications of the ACM, 52(8), 105-110.

Chen, M-C., Cheng, S.-J., \& Hwang, Y. (2005). An empirical investigation of the relationship between intellectual capital and firms' market value and financial performance. Journal of Intellectual Capital, 6(2), 159-176.

Coad, A., \& Rao, R. (2010). Firm growth and R\&D expenditure. Economics of Innovation and New Technology, 19(2), 127-145.

Dave, P., Wadhwa, V., Aggarwal, S., \& Seetharaman, A. (2013). The impact of research and development on the financial sustainability of information technology (IT) companies listed on the S\&P 500 index. Journal of Sustainable Development, 6(11), 122.

Denicolai, S., Zucchella, A., \& Strange, R. (2014). Knowledge assets and firm international performance. International Business Review, 23(1), 55-62.

Eberhart, A. C., Maxwell, W. F., \& Siddique, A. R. (2004). An examination of long-term abnormal stock returns and operating performance following R\&D increases. The Journal of Finance, 59(2), $623-$ 650.

Gamayuni, R. R. (2015). The effect of intangible asset, financial performance and financial policies on the firm value. International Journal of Scientific \& Technology Research, 4(1), 202-212.

García-García, J., \& de Magdaleno, M. A. (2010). Fair value on Open Source business. XIV Encuentro AECA, Coimbra (Portugal). 
Garger, J. (2010). Equity and market value: How much is a company worth to an investor.

Grant, R. M. (1996). Toward a knowledge-based theory of the firm. Strategic Management Journal, 17(S2), 109-122.

Hall, B. H., \& Lerner, J. (2010). The financing of R\&D and innovation. In Handbook of the Economics of Innovation (Vol. 1, pp. 609-639): Elsevier.

Helfat, C. E., \& Peteraf, M. A. (2003). The dynamic resource-based view: Capability lifecycles. Strategic Management Journal, 24(10), 997-1010.

Hsieh, P-H., Mishra, C. S., \& Gobeli, D. H. (2003). The return on R\&D versus capital expenditures in pharmaceutical and chemical industries. IEEE Transactions on Engineering Management, 50(2), 141-150.

Hsu, I-C., \& Sabherwal, R. (2011). From intellectual capital to firm performance: the mediating role of knowledge management capabilities. IEEE Transactions on Engineering Management, 58(4), 626-642.

Hulten, C. R., \& Hao, X. (2008). What is a Company Really Worth? Intangible Capital and the" Market to Book Value" Puzzle.

Jirásek, M. (2017). The Relationship Between R\&D Spending Instability and a Firm's Performance.

Jirásek, M. (2018). Financial Performance Feedback and R\&D: A Comparison of Different Models. Quality Innovation Prosperity, 22(1), 01-13.

Kalleberg, A. L., Marsden, P. V., Reynolds, J., \& Knoke, D. (2006). Beyond profit? Sectoral differences in high-performance work practices. Work and Occupations, 33(3), 271-302.

Kianto, A., Andreeva, T., \& Pavlov, Y. (2013). The impact of intellectual capital management on company competitiveness and financial performance. Knowledge Management Research \& Practice, 11(2), 112-122.

Kogut, B., \& Zander, U. (1992). Knowledge of the firm, combinative capabilities, and the replication of technology. Organization Science, 3(3), 383-397.

Kothari, S., Laguerre, T. E., \& Leone, A. J. (2002). Capitalization versus expensing: Evidence on the uncertainty of future earnings from capital expenditures versus R\&D outlays. Review of accounting Studies, 7(4), 355-382.

Lantz, J-S., \& Sahut, J-M. (2005). R\&D investment and the financial performance of technological firms. International Journal of Business, 10(3), 251.

Leitner, K. H. (2005). Managing and reporting intangible assets in research technology organisations. $R \& D$ Management, 35(2), 125-136.

Lin, C.-H., Yang, H.-L., \& Liou, D.-Y. (2009). The impact of corporate social responsibility on financial performance: Evidence from business in Taiwan. Technology in Society, 31(1), 56-63.

Lome, O., Heggeseth, A. G., \& Moen, Ø. (2016). The effect of R\&D on performance: Do R\&D-intensive firms handle a financial crisis better? The Journal of High Technology Management Research, 27(1), 65-77.

Marrocu, E., Paci, R., \& Pontis, M. (2011). Intangible capital and firms' productivity. Industrial and Corporate Change, 21(2), 377-402.

Martin, M. (2015). Effectiveness of Business Innovation and R\&D in Emerging Economies: The Evidence from Panel Data Analysis. Journal of Economics Business and Management, 3(4), 440446.

Menor, L. J., Kristal, M. M., \& Rosenzweig, E. D. (2007). Examining the influence of operational intellectual capital on capabilities and performance. Manufacturing \& Service Operations Management, 9(4), 559-578.

Pandit, S., Wasley, C. E., \& Zach, T. (2011). The effect of research and development (R\&D) inputs and outputs on the relation between the uncertainty of future operating performance and R\&D expenditures. Journal of Accounting, Auditing \& Finance, 26(1), 121-144.

Penman, S.H. (2009), Accounting for intangible assets: there is also an income statement. Abacus, 45(3), 358-371. 
Peterson, R. A., \& Jeong, J. (2010). Exploring the impact of advertising and R\&D expenditures on corporate brand value and firm-level financial performance. Journal of the Academy of Marketing Science, 38(6), 677-690.

Rafiq, S., Salim, R., \& Smyth, R. (2016). The moderating role of firm age in the relationship between R\&D expenditure and financial performance: Evidence from Chinese and US mining firms. Economic Modelling, 56, 122-132.

Schimke, A., \& Brenner, T. (2014). The role of R\&D investments in highly R\&D-based firms. Studies in Economics and Finance, 31(1), 3-45.

Sehrawat, M., \& Giri, A. (2017). A Sectoral Analysis of the Role of Stock Market Development on Economic Growth: Empirical Evidence from Indian Economy. Global Business Review, 18(4), 911-923.

Sher, P. J., \& Yang, P. Y. (2005). The effects of innovative capabilities and R\&D clustering on firm performance: the evidence of Taiwan's semiconductor industry. Technovation, 25(1), 33-43.

Shin, N., Kraemer, K. L., \& Dedrick, J. (2009). R\&D, value chain location and firm performance in the global electronics industry. Industry and Innovation, 16(3), 315-330.

Siegel, J. J., \& Schwartz, J. D. (2006). Long-term returns on the original S\&P 500 companies. Financial Analysts Journal, 62(1), 18-31.

Teirlinck, P. (2017). Configurations of strategic R\&D decisions and financial performance in small-sized and medium-sized firms. Journal of Business Research, 74, 55-65.

Tubbs, M. (2007). The relationship between R\&D and company performance. Research-Technology Management, 50(6), 23-30.

VanderPal, G. A. (2015). Impact of R\&D Expenses and Corporate Financial Performance. Journal of Accounting and Finance, 15(7), 135.

Wang, C.-H. (2011). Clarifying the Effects of R\&D on Performance: evidence from the high technology industries. Asia Pacific Management Review, 16(1), 51-64. 